\title{
DETERMINANT OF FRAUD PENTAGON IN DETECTING FINANCE OF FINANCIAL STATEMENTS
}

\author{
Muhammad Bagus, Noviansyah Rizal, Siwidyah Desi Lastianti \\ Departement of Accountinng, STIE Widya Gama Lumajang, Indonesia \\ Universitas Merdeka Surabaya
}

Email: noviansyah.rizal@gmail.com

\section{A R T I C LE INFO}

Date of entry:

15 Oktober 2019

Revision Date:

27 November 2019

Date Received:

17 Desember 2019

\begin{abstract}
A B S T R A C T
This study aims to determine the Pentagon Determinant Fraud in detecting fraudulent financial statements. Fraudulent financial statements are proxied by the Fraud Score Model. Whereas the pressure factor is proxied by insisting from within, for the opportunity factor proxied by industry conditions, the rationalization factor is proxied by the ratio of total accruals, the competency factor is proxied by the change of directors and arrogance is proxied by the duality of quality positions at the CEO. The population in this study amounted to 100 companies incorporated in the compass index 100 contained in the Indonesia Stock Exchange and for the sample of the study were 35 companies belonging to the compass index 100 contained in the Indonesia Stock Exchange, which was selected using the purposive sampling method for the 2017-2018 period. Data were analyzed using multiple linear regression. Based on the test results, it was concluded that the pentagon fraud component included internal pressure (LEV), industry conditions (INVENTORY), rationalization (TATA) influencing financial statement fraud while competence (DCHANGE) and arrogance (DCD) had no effect on financial fraud statement. This proves that internal pressure (LEV), industry conditions (INVENTORY), and rationalization (TATA) can be used to detect fraud in financial statements.
\end{abstract}

Keywords: pressure, opportunity, rationalization, competence, and arrogance.

Cite this as: Bagus, M., Rizal, N., Lastianti, S. D. (2020). DETERMINANT OF FRAUD PENTAGON IN DETECTING FINANCE OF FINANCIAL STATEMENTS.

Assets : Jurnal Ilmiah Ilmu Akuntansi, Keuangan dan Pajak, 4(1), 32-41

\section{INTRODUCTION}

Financial statements are the main factor in evaluating company performance. The management must manage the company to report a company's financial performance to shareholders. How important is the financial statements for the company, management often covers the real situation of the financial statements so that their performance looks good by cheating financial reporting on the company(Agustina and Pratomo, 2019)? Companies want to be considered good from all parties, with this company that encourages manipulating information in certain sections that are presented to the public - the emergence of fraud by the relationship between agent and principal. 
Shareholders give confidence to the management to manage shares, so that management tries its best to manage the company even though it is not good. Between management and companies, sometimes experience disputes due to management's lack of supervision of the interests of shareholders resulting in disputes(Ulfah et al., 2017).

Association of Certified Fraud Examiner(2016), has its own understanding of increasing fraud in financial statements than other frauds. Fraud in financial statements is very detrimental because the presentation in financial information becomes incorrect and unreliable because it makes mistakes in making decisions. Many frauds occur both in Indonesia and abroad. Every company wants to make good financial reports, and this is a motivation for management to improve its performance also encourage management to commit fraud(Setiawati and Baningrum, 2018). ACFE, (2016) also explained that the biggest fraud occurred in misappropriation of assets (Asset Misappropriation) which occurred in $19 \%$ of cases, Corruption (77\%), and Fraud of Financial Statements (Financial Statement Fraud) 4\%, even though the percentage was small, the total amount of losses was very high and always increased compared to corruption and misuse of assets.

According to research, Bawekes et al. (2018) explain one of the most notorious cases of financial statement fraud, the Enron case. The merger of the company between Inter North and Houston Natural Gas was established in 1985. Enron is a company engaged in the energy industry. The company focuses on many sectors, including future transactions, trade-in non-financial commodities, and other business activities. In December 2001, it was revealed that the Enron case began to be revealed and continued until 2002 with quite extensive problems. The Enron company scandal involved a public accounting office, Arthur Andersen's Public Accounting Firm. The way the Enron company to look good in the eyes of investors does not look good but instead brings the Enron company into big trouble.

Another cheating case according to Agustina and Pratomo (2019), as was the case with PT Cakra Mineral Tbk (CKRA) in 2016 that PT CKRA's board of directors had been reported to the Indonesia Stock Exchange (IDX) and OJK due to cases of manipulation and embezzlement of corporate accounting and counterfeiting directed by Boedi Muliadi, the president director proved to be manipulating and exceeds the value of assets and paid-in capital. The development of the era and extensive knowledge about fraud seen from previous research that provides an overview of the practice of financial statement fraud. One of the most famous is the research conducted by Cressey (1953), in his research entitled "Other People's Money: A Study in The Social Psychology of Embezzlement" Cressey coined a theory of fraud known as a triangle theory with three factors that encourage fraud, namely (1) pressure (pressure), (2) opportunity, (3) rationalization.

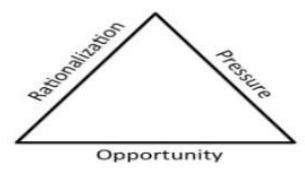

Figure 1 Fraud Triangle

Source: ACFE (2016)

According to research Ulfah et al. (2017), diamond fraud is a research development of the fraud triangle. This theory emerged and was introduced by Wolfe and Hermanson (2004)by increasing prevention and detecting fraud by considering new variables with the addition of an individual ability consideration. Competence (competence) is a form of individual ability possessed by someone. According to Wolfe and Hermanson (2004)explains that more billions of fraud will not occur if the person does not have the right skills. The great opportunity to commit fraud, both pressure and rationalization, which attracts people to commit fraud (fraud), also there must be an opportunity to take advantage of it in every company. 


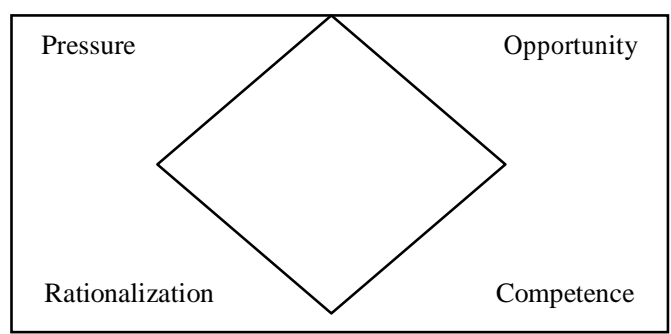

Figure 2. Diamond Theory Fraud (Quadrilateral Cheating)

Sources: Wolfe and Hermanson (2004)

Ulfah et al. (2017), stated that fraud pentagon is a research development of diamond fraud with the addition of two variables, namely competence and arrogance. Competence is part of the ability of someone trying to commit fraud with the high position of someone in each company very likely to commit fraud. Arrogance is shown by the attitude of feeling that someone is free from all policies, both regulations and internal controls in each company, and feels that he has never committed fraud (fraud) in the company.

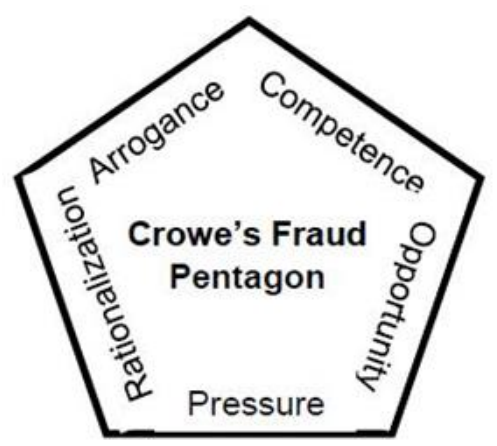

Figure 3. Pentagon Theory Fraud (Five Fraud Cheats)

Source: Crowe Howart (2012)

Fraudulent financial statements can be detected using the pentagon fraud method, which consists of pressure, opportunity, rationalization, competence, and arrogance. Pentagon Theory Fraud has five elements or variables including pressure, according to researchDamayani et al. (2019)explain that pressure is an incentive to commit fraud, lifestyle and economic pressures that encourage companies or managers to manipulate data on a financial report when there is a decline or near bankruptcy of a company. Pressure can be proxied by external pressure, due to the high pressure experienced by management to meet all expectations of third parties, by overcoming these problems or all pressures the company requires a lot of debt or more capital for external costs, so the company growing or competitive, research funding and development or capital expenditure (Bawekes et al., 2018: 123).

Opportunity is a condition that can provide benefits for management in committing all forms of fraud, such as the board of directors of a company that never oversees all the details of a company's financial statements(Damayani et al., 2019). WhileIsmawati and Krisnawati (2017), the opportunity is also a condition where the opportunity to commit a crime by manipulating all data and financial information of a company that is carried out due to lack of supervision from the company which can be an opportunity for the perpetrators of this fraud. The perpetrators of this fraud emerged due to non-compliance with internal oversight or internal audit for the committee. Opportunity (opportunity) can be proxied by the nature of the industry due to the ideal state of a company in developing its industry. In a financial statement, there is an account that is easily 
determined by the company based on the estimated value of the company. The easiest account to control is the inventory account (Pardosi, 2015).

Rationalization can occur due to fraud seeking justification for all activities that impact fraud. Actors usually look for many rational reasons to justify all their actions, such as earning management, is the main factor in the occurrence of an act of cheating financial statements. Earning management is an impact of the users of the accrual principle of every financial statement preparation because it is considered more fair and rational. The weakness of this system can be moved (tuned) to change the figure of a profit generated by a company so that it can lead to fraud in financial reporting. This accrual principle is used as a decision for management and provides insight into rationalization in every financial reporting (Ismawati and Krisnawati, 2017).

Competency is an actor's skill to disregard the company's internal controls and deliberately develop a concealment strategy by observing the company's social conditions to satisfy the desires of his personal interests, without the existence of high ability, the fraud will not arise in the company (Ismawati and Krisnawati 2017). According to researchSeptriani and Handayani (2018), stated that companies that commit fraud often make changes in the composition of the directors due to the unstable state of the company. Change of directors is the main factor in the political interests of each board of directors, in reducing all effectiveness of all management performance so that it adapts to the performance of new directors.

Arrogance is another form of arrogance or lack of conscience as an arrogant nature for someone who believes that internal control cannot be enforced personally or individually Agustina and Pratomo (2019). A high level of arrogance causes a lot of fraud because the arrogant attitude of the CEO can do everything he can to stay in that position, both in his current position or position. A CEO wants to show outsiders the current status in the company because they don't want to lose their current position(Septriani and Handayani, 2018).

CEO of Dualityhas a relationship with agency theory, which explains that the possibility of the CEO holding more than one position, then the CEO will use the power he has today for his own benefit. This condition has an impact on the lack of a supervisory function within the company that will be used by several parties to commit fraud so that conflicts of interest between the agent and the principal have increased(Ratnasari and Solikhah, 2019). According toSasongko and Wijayantika (2019), CEO duality will cause bad corporate governance because the CEO is not able to perform functions in supervision that are separate from his personal interests and arrogant nature because he has more than one position so that the greater the fraud.

Fraudulent financial statements are measured using the F-Score model, which is the sum of two accrual quality and financial performance variables. Arrival quality is proxied by RSST actual, while financial performance variables are proxied by changes in accounts receivable, changes in inventory accounts, changes in cash sales accounts, changes to the profit account (EBIT) (Damayani et al., 2019). Researchers relating to pentagon fraud have been carried out by Sasongko and Wijayantika (2019)it can be concluded that the external pressure variable, the nature of industry variable, the change of directors variable, CEO duality does not have a significant effect on financial statement fraud. Research relating to pentagon fraud was also conducted byRatnasari and Solikhah (2019), it can be concluded that external pressure, nature of the industry, change of directors, and CEO duality variables have a significant effect on financial statement fraud. Research on Pentagon Fraud has also been studied by Ismawati and Krisnawati (2017), who argued that the external pressure variable, nature of the industry, changes in directors affect the financial statement fraud.

Septriani and Handayani (2018) and Siddiq and Suseno (2019), who tried to prove the truth of the Pentagon fraud theory research with the results of the external pressure variable, the nature of the industry, the change of directors had no effect on financial statement fraud. But in many studies, 
there are differences in results between researchers. Therefore, researchers try to do research again to prove the validity of the theory, especially in the pentagon fraud theory, because it is considered to cover all the variables in the previous theory, namely diamond fraud.

\section{METHODS}

This type of research is a quantitative descriptive study. The object of this research is external pressure, nature of industry, rationalization, competence, arrogance, and fraudulent financial statements of companies contained in the Kompas 100 index on the Indonesia Stock Exchange. The type of data used in this study is secondary data, and the data sources used are internal data. In this study, the population used is all companies contained in the Kompas 100 index listed on the Indonesia Stock Exchange period 2017-2018. Consideration of the selection of companies contained in the compass 100 indexes as an object of research because the companies contained in the compass 100 index have a longer business process when compared with other types of industries, high liquidity, large market capitalization, and is a stock that has fundamentals and high performance when compared to other types of industries. The sampling technique used in this study is the purposive sampling method. With 35 samples each year that meet the sample criteria, so the samples in this study were 70 companies.LangWhether, the data analysis of this research consists of the Classical Assumption Test, the Multiple Linear Regression Model, and the Hypothesis Test.

\section{RESULTS AND DISCUSSION}

Variable research on the influence of External Pressure, Nature of Industry, Rationalization, Competence, and Arrogance (CEO Duality) follows the normal distribution with an asymptotic significance value of more than 0.05 , which is 0.110 which means that the data is normally distributed. Tolerance values for the External Pressure variable $(0,963)$, Nature Of Industry $(0,302)$, Rationalization $(0,319)$, Competence $(0,855)$, and Arrogance $(0,880)$ were stated not to occur multicollinearity symptoms due to tolerance values> 0.10 . VIF values for the External Pressure variable (1,038), Nature Of Industry (3,313), Rationalization (3,312), Competence $(1,169)$, and Arrogance $(1,136)$ are stated as not having multicollinearity symptoms due to VIF values $<10$. From the Park Test results above it can be concluded that the significant value of the External Pressure variable (0.996), Nature Of Industry (0.046), rationalization (0.226), Directors' Change (0.749), and CEO Duality (0.439) with a Significant value of $\geq 0.05$ so that the data This does not happen heteroskesdasitas. From the results of the autocorrelation test calculations above show that the Durbin Watson (DW) value of 2.059 By looking at the Watson Durbin table, the dL value is 1.4637 while the $\mathrm{dU}$ value is 1.7683 . Suppose entered into the formulation $\mathrm{DU}<\mathrm{DW}<(4-$ $\mathrm{DU})$, the result is $1.7683<2.059<2.2362$. So it can be concluded that the HO linear regression model is accepted, which states that there is no autocorrelation, and there is no lag variable between the independent variables.

Rationalization (0.226), Change of Directors (0.749), and CEO Duality (0.439) with a Significant value of 00.05 so that the data does not occur heteroscience. From the results of the autocorrelation test calculations above show that the Durbin Watson (DW) value of 2.059 By looking at the Watson Durbin table, the $\mathrm{dL}$ value is 1.4637 while the $\mathrm{dU}$ value is 1.7683 . Suppose entered into the formulation $\mathrm{DU}<\mathrm{DW}<(4-\mathrm{DU})$, the result is $1.7683<2.059<2.2362$. So it can be concluded that the HO linear regression model is accepted, which states that there is no autocorrelation, and there is no lag variable between the independent variables. Rationalization (0.226), Change of Directors (0.749), and CEO Duality (0.439) with a Significant value of 00.05 so that the data does not occur heterosecurity. From the results of the autocorrelation test calculations above show that the Durbin Watson (DW) value of 2.059 By looking at the Watson Durbin table, the dL value is 1.4637 while the $\mathrm{dU}$ value is 1.7683. Suppose entered into the formulation $\mathrm{DU}<\mathrm{DW}<(4-\mathrm{DU})$, the result is 
$1.768<2.059<2.2362$. So it can be concluded that the HO linear regression model is accepted, which states that there is no autocorrelation, and there is no lag variable between the independent variables. From the results of the autocorrelation test calculations above show that the Durbin Watson (DW) value of 2.059 By looking at the Watson Durbin table, the dL value is 1.4637 while the $\mathrm{dU}$ value is 1.7683. Suppose entered into the formulation $\mathrm{DU}<\mathrm{DW}<(4-\mathrm{DU})$, the result is $1.7683<2.059<2.2362$. So it can be concluded that the HO linear regression model is accepted, which states that there is no autocorrelation, and there is no lag variable between the independent variables. From the results of the autocorrelation test calculations above show that the Durbin Watson (DW) value of 2.059 By looking at the Watson Durbin table, the dL value is 1.4637 while the $\mathrm{dU}$ value is 1.7683. Suppose entered into the formulation $\mathrm{DU}<\mathrm{DW}<(4-\mathrm{DU})$, the result is $1.7683<2.059<2.2362$. So it can be concluded that the HO linear regression model is accepted, which states that there is no autocorrelation, and there is no lag variable between the independent variables.

The results of the regression analysis showed that the value of the resulting constant was 1.194; Regression coefficient for External Pressure (LEV) of -, 451; Nature of Industry (INVENTORY) coefficient of -2.442; Rationalization coefficient (TATA) of 2.976; Competence (DCHANGE) of , 248; and Arrogance (DCD) of -, 145.The equation of the multiple regression model developed to test the hypotheses that have been formulated in this study are: $\mathrm{Y}=\alpha+\beta 1 \mathrm{X} 1+\beta 2 \mathrm{X} 2+\beta 3 \mathrm{X} 3+$ $\beta 4 \mathrm{X} 4+\beta 5 \mathrm{X} 5+\mathrm{e}$ so that the following equation can be entered: $\mathrm{Y}=1,194-1,451(\mathrm{X} 1)-2,428$ $(\mathrm{X} 2)+2,976(\mathrm{X} 3)-0,248(\mathrm{X} 4)-0,145(\mathrm{X} 5)+\mathrm{e}$.

The calculation of the regression model produces an R-value of 0.195 which means that the dependent variable is Financial Statement Fraud can be explained by the independent variables External Pressure, Nature of Industry, Rationalization, Competence and Arrogance (CEO) Duality) of $19.5 \%$ is classified as high-level financial statement fraud because the percentage is close to $4 \%$ and the rest is explained by other variables outside the model in this study. The independent variable as a whole and the remaining $80.5 \%$ of the other variables that are not explained and examined in this study. Simultaneous test results show the calculated F value of 4.377 with a significance of 0.002 . The significance value is smaller than 0.05 which is equal to 0 , In the $t$-test (alpha) 0.05 on the independent variable after being tested produced the following findings: In the independent variable, External Pressure found that the significance value $\leq 0.05$ is 0.005 . This indicates that $\mathrm{H} 1$ can be accepted, and this means that External Pressure has a significant effect on the detection of fraudulent financial statements. In the independent variable Nature of Industry, it was found that the significance value $>0.05$ is 0.010 . This indicates that $\mathrm{H} 2$ can be accepted, and this means that the Nature of Industry has a significant effect on the detection of fraudulent financial statements. In the independent variable rationalization found that the significance value score 0.05 is 0.001 . This indicates that $\mathrm{H} 3$ is acceptable, and this means that rationalization has a significant effect on the detection of fraudulent financial statements. In the independent variable, Competence (Substitution of Directors) found that the significance value> 0.05 is 0.335 . This indicates that $\mathrm{H} 4$ cannot be accepted, and this means that competence does not have a significant effect on the detection of fraudulent financial statements. In the independent variable, Arrogance (CEO Duality) found that the significance value $>0.05$ is 0.414 . This indicates that H5 cannot be accepted, and this means that competence has no significant effect on the detection of fraudulent financial statements. 05 , which is 0.335 .

Hypothesis testing results (H1) External Pressure as measured by LEV has a negative coefficient of $-1,451$, indicating that any increase in external pressure (LEV) of 1 unit of potential financial statement fraud will decrease by $1.451 \%$ on the basis of the percentage of fraud ranging from nominal cheating from 1 billion rupiahs up to 5 billion rupiahs are in appendix 25 , and the significance level $t$ is 0.005 with a regression coefficient with a sig $t$ level $\leq 0.05$ This value means that External Pressure affects the detection of fraudulent financial statements. This event shows that the greater the value of the ratio of total debt to total assets in a company, management considers that the pressure that comes from debt can influence them to commit fraud. This happens 
because the company lacks capital, so it makes pressure for management to seek additional capital in various ways. Companies also tend to choose to increase funding through additional debt to outsiders. The company has the confidence to get a capital injection from the source of debt, business processes in the company will get better and increase so that it will get a refund, but sometimes what is planned does not match what is desired, so the company cannot pay debt bills smoothly. That is why the management is trying to manipulate the level of debt repayment so that the company's financial condition looks stable, with this condition the company requires huge profits to convince shareholders that they are able to pay the debt used in a company's operational research. The results of this study are supported by research conductedSkousen and Wright (2011)andSeptriani and Handayani (2018) with the results of research, which states that the External Pressure variable has a significant positive effect on financial statement fraud.

Hypothesis testing results (H2) Nature of Industry as measured by INVENTORY has a coefficient of $-2,428$ indicating that for every increase in nature of the industry (INVENTORY) by 1 unit, the potential for financial statement fraud will decrease by $2.428 \%$ on the basis of the percentage of fraud starting from 500 million rupiahs up to 1 billion rupiahs contained in annex 25 and the significance level of $t$ is 0.010 with a regression coefficient with a sig $t$ level $\leq 0.05$. This value means that the Nature of Industry influences the detection of financial statement fraud. This happens because inventory turnover with sales is also high due to obsolete inventory at the company. The company will emphasize the amount of inventory by increasing the number of sales. Nature of industry, an idealistic state of a company in its industry, in reporting inventories is part of current assets that are prone to be stolen and rigged because they are real goods and are very easy to sell, so they get money directly. In this case, the company's company inventory is in good condition and under control because of smooth sales. This allows the company to manipulate financial statement fraud because the estimated value of inventories is determined by the company itself. The results of this study are supported by research conductedSiddiq and Suseno (2019) with the results which state that the Nature of Industry variable has a significant effect on financial statement fraud.

The results of hypothesis testing (H3) rationalization measured by TATA (Total Assets to Total Accrual) have a coefficient of 2.976 indicating that each increase in rationalization (TATA) by 1 unit, the potential for financial statement fraud will increase by $2.976 \%$ on the basis of the percentage of fraud starting from 1 billion rupiahs to 5 billion rupiahs contained in appendix 26 and the significance level of $t$ is 0.001 with a regression coefficient with a level of sig $t \leq 0.05$. This value means that rationalization affects the detection of financial statement fraud. Total Accrual can be used to describe and measure rationalization related to the use of the accrual principle by management so that rationalization affects the detection of financial statement fraud. TATA calculation on the company affects the detection of fraudulent financial statements. This happens because management sets principles in its calculations, so that management has the opportunity to commit financial reporting fraud. The results of this study are supported by research conductedSiddiq and Suseno (2019) with the results of research, which states that the Rationalization variable significantly influences financial statement fraud.

Hypothesis testing results (H4) competence as measured by DCHANGE has a coefficient of -. 248 , indicating that each capability increase (DCHANGE) by 1 unit, the potential for financial statement fraud will decrease by $0.248 \%$ on the basis of the percentage of fraud from 50 million rupiahs to 100 million rupiahs contained in appendix 25 and the level of significance $t$ of 0.335 with a regression coefficient with a level of sig $t \geq 0.05$. This value means that competence does not affect the potential for financial statement fraud. No matter how often the change of directors in a company, does not affect the potential for fraudulent financial statements and the greater or lesser value of the change of directors does not affect the fraudulent financial statements. The substitution of directors in the company does not affect the potential for fraudulent financial statements. This happens because the change of directors is not because the old directors used their ability to commit fraud but because it was caused by something else. In addition, the change of 
directors was successful because the new directors could use their position to further advance the company and prevent fraud. The results of this study are supported by research conductedSeptriani and Handayani (2018) with the results of research that state that the Capability variable does not affect financial statement fraud.

Because there are many other conditions that cause an impact on the low level of supervision function within the company, which will be used by several parties to commit fraud, such as conducting cooperation between companies by agreeing on other agreements that benefit both parties, so the conflict of interest between the agent and the principal has increased, so CEO duality is not the main factor that causes bad corporate governance, because the CEO has another way for his personal interests by manipulating others in order to commit fraudulent financial statements because the company has a member or CEO with the dualism of their positions, they use their positions to improve company performance and maintain performance in order to remain in the company. At the same time, companies that do not have dualism of their positions are more focused on carrying out their jobs well so that their performance looks good in the eyes of the company. The results of this study are supported by research conductedSasongko and Wijayantika (2019) with the results of research, which states that the Arrogance variable (CEO Duality) has no effect on financial statement fraud.

\section{CONCLUSION}

The test results based on the coefficient of determination test (R2) showed a value of 0.195 is the dependent variable cheating financial statements can be explained by the independent variable external pressure, nature of industry, rationalization, competence, and arrogance of $19.5 \%$ and the rest is explained by other variables outside the model in this study. The independent variable as a whole and the remaining $80.5 \%$ of the other variables that are not explained and examined in this study. The test results based on simultaneous tests $(F)$ states that external pressure, nature of industry, rationalization, competence, and arrogance have an overall effect on the detection of financial statement fraud. The test results based on a partial test $(\mathrm{t})$ states that competence and arrogance have no effect on the detection of financial statement fraud, while for external pressure, nature of the industry, and rationalization have a significant effect on the detection of financial statement fraud.

Further research is expected to increase the period of the financial statements understudy so that more samples are obtained, and the results can reflect the actual conditions and are expected to add more variables used to detect financial statements, add proxy variables such as financial targets with ineffective monitoring, nature of the industry with receivable proxy, rationalization with audit opinion proxy, competency using public accounting change proxy (AUDCHG) and arrogance with a frequent number of CEO (CEOPIC) proxy using other new indicators that are considered appropriate to be used, for example using fraud pentagon analysis in detecting fraudulent financial statements using the Beneish M Model (M Score) method. For users of financial statements can use Leverage (LEV), Nature of Industry (INVENTORY) and Total Accrual to Total Assets (TATA) as a detector of financial statement fraud because in this study the ratio is proven to be influential to be used as an indicator of financial statement fraud

\section{REFERENCE}

ACFE. (2016). Survai Fraud In Indonesia. Association of Certified Fraud Examiners (Indonesia Chapter \#111), 1-62.

Agustina, R. D., \& Pratomo, D. (2019). Pengaruh Fraud Pentagon Dalam Mendeteksi Kecurangan Pelaporan Keuangan. Jurnal Ilmiah Manajemen, Ekonomi, \& Akuntansi (MEA), 3(1), 4462. https://doi.org/10.31955/mea.vol3.iss1.pp44-62 
Arens, A.A; Elder, R.J;Beasley, M. . (2011). Auditing \& Jasa Assurance. Salemba Empat.

Bawekes, H. F., Simanjuntak, A. M. A., \& Daat, S. C. (2018). Pengujian Teori Fraud Pentagon Terhadap Fraudulent Financial Reporting (Studi Empiris pada Perusahaan yang Terdaftar di Bursa Efek Indonesia Tahun 2011-2015). Jurnal Akuntansi \& Keuangan Daerah, 13(1), 114-134.

Cressey, D. (1953). Encyclopedia of Criminological Theory Cressey, Donald R.: Embezzlement and White-Collar Crime Contributors:

Damayani, F., Wahyudi, T., \& Yuniartie, E. (2019). Pengaruh Fraud Pentagon Terhadap Kecurangan Laporan Keuangan Pada Perusahaan Infrastruktur Yangterdaftar Di Bursa Efek Indonesiatahun 2014 - 2016. AKUNTABILITAS: Jurnal Penelitian Dan Pengembangan Akuntansi, 11(2), 151-170. https://doi.org/10.29259/ja.v11i2.8936

Fitrawansyah. (2014). Fraud \& Auditing. Mitra Wacana Media.

Ghozali, I. (2016). Aplikasi Analisis Multivariete Dengan Program IBM SPSS 23. Badan Penerbit Universitas Diponegoro.

Gunawan, I. (2017). Pengantar Statistik Inferensial Ed. 1, Cet. 2. Raja Grafindo Persada.

Ismawati, D; Krisnawati, L. (2017). Analisis Fraud Pentagon Pada Financial Statement Fraud Menggunakan Beneish M-Score Dan F-score. ABA Journal, 102(4), 24-25. https://doi.org/10.1002/ejsp. 2570

Nasution, M; Suryani, E; Lestari, T. (2019). Pengaruh Fraud Pentagon Terhadap Kecurangan Laporan Keuangan (Studi Pada Perusahaan Manufaktur Sub Sektor Makanan Dan Minuman Yang Terdaftar Di Bursa Efek Indonesia). Jurnal Aksara Public, 3, 5-10.

Paramita, R; Rizal, N. (2018). Metode Penelitian Kuantitatif. AZYAN MITRA MEDIA.

Pardosi, R. W. (2015). Analis Fraud Diamond Dalam Mendeteksi Kecurangan Laporan Keuangan Pada Perusahaan Manufaktur Di Indonesia Dengan Menggunakan Fraud Score Model Tahun 2010-2013. Skripsi, 53(9), 1-72. https://doi.org/10.1017/CBO9781107415324.004

Pratiwi, N; Nurbaiti, A. (2018). Analisis Fraud Pentagon Dalam Mendeteksi Kecurangan Laporan Keuangan Dengan Metode F-Score Model (Studi Empiris Pada Perusahaan Pertambangan Yang Terdaftar Di Bursa Efek Indonesia. E- Proceeding of Management, 03(01), 18-31.

Rahmawati, M. (2013). Pendeteksian Kecurangan Laporan Keuangan Melalui Faktor Risiko Tekanan Dan Peluang (Studi Kasus pada Perusahaan yang Mendapat Sanksi dari Bapepam Periode 2002-2006). Diponegoro Jurnal Of Accounting, 2, 700-711.

Ratnasari, E; Solikhah, B. (2019). Analysis Of Fraudulent Financial Statement: The Fraud Pentagon Theory Approach Analisis Kecurangan Laporan Keuangan: Pendekatan Fraud Pentagon Theory. Gorontalo Accounting Journal (GAJ, 2(2), 98-112.

Sasongko, N., \& Wijayantika, S. F. (2019). Faktor Resiko Fraud Terhadap Pelaksanaan Fraudulent Financial Reporting (Berdasarkan Pendekatan Crown'S Fraud Pentagon Theory). Riset Akuntansi Dan Keuangan Indonesia, 4(1), 67-76. https://doi.org/10.23917/reaksi.v4i1.7809

Septriani, Yossi; Handayani, D. (2018). Mendeteksi Kecurangan Laporan Keuangan dengan Analisis Fraud Pentagon. Jurnal Akuntansi, Keuangan Dan Bisnis, 11(1), 11-23. http://jurnal.pcr.ac.id 
Setiawati, E., \& Baningrum, R. M. (2018). Deteksi Fraudulent Financial Reporting Menggunakan Analisis Fraud Pentagon: Studi Kasus Pada Perusahaan Manufaktur Yang Listed Di BEI Tahun 2014-2016 Riset Akuntansi dan Keuangan Indonesia , 3 ( 2 ), 2018. Riset Akuntansi Dan Keuangan Indonesia, 3(1953), 91-106.

Siddiq, F; Suseno, A. (2019). Fraud Pentagon Teori Dalam Financial Statement Fraud Pada Perusahaan Terdaftar Di Jakarta Islamic Indek (JII) Periode 2014-2017. Jurnal Nusamba, 4(2), 128-138. https://doi.org/10.29407/nusamba.v4i2.13800

Skousen, C. J., \& Wright, C. J. (2011). Contemporaneous Risk Factors and the Prediction of Financial Statement Fraud. In SSRN Electronic Journal. https://doi.org/10.2139/ssrn.938736

Suliyanto, H. (2008). Manajemen Laba. Grasindo.

Ulfah, M., Nuraina, E., \& Wijaya, A. L. (2017). Pengaruh Fraud Pentagon dalam Mendeteksi Fraudulent Financial Reporting (Studi Empiris pada Perbankan di Indonesia yang Terdaftar di BEI). The 9th Forum Ilmiah Pendidikan Akuntansi (FIPA), VOL 5 NO 1, 399-418. http://prosiding.unipma.ac.id/index.php/FIPA/article/viewFile/291/272

Wolfe, D. T., \& Hermanson, D. R. (2004). The Fraud Diamond : Considering the Four Elements of Fraud: Certified Public Accountant. The CPA Journal, 74(12), 38-42. https://doi.org/DOI: 